\title{
Religion-Making in the Disney Feature Film, Frozen II: Indigenous Religion and Dynamics of Agency
}

\section{Trude Fonneland}

The Arctic University Museum of Norway and Academy of Arts (UMAK), UiT-The Arctic University of Norway, P.O. Box 6050, N-9037 Langnes Tromsø, Norway; trude.fonneland@uit.no

Received: 4 August 2020; Accepted: 19 August 2020; Published: 21 August 2020

\begin{abstract}
This paper explores the religion-making potential of a particular secular institution, namely the Walt Disney Studios. Focusing on the animation film Frozen II that was launched in November 2019, the current article enters into debates about the manner in which indigenous religion is part of the commodity presented-how religion is produced, packaged, and staged. In the article I argue that contemporary media-scapes can be seen as agents of religion-making, of religious circulation, and renewal. As such, religion, as it is expressed in Frozen II, is outlined and produced by a particular media-form and shaped as a popular cultural formation. Further discussions about cultural appropriation are highlighted, focusing on how Disney's reach out for cooperation with the Sámi community can generate new cultural policies and practices.
\end{abstract}

Keywords: Frozen II; indigenous religion; religion-making; appropriation; collaboration

\section{Introduction}

Frozen II had its world premiere at the Dolby Theatre in Hollywood on 7 November 2019, was released in the United States by Walt Disney Studios on 22 November 2019, and is ranked as one of the highest grossing animated movies of all time. ${ }^{1}$ The sequel to the 2013 film Frozen provides a reunion with the famous royal sisters Elsa and Anna and their friends, the high-spirited snowman Olaf, the reindeer Sven and the ice harvester and deliverer, Kristoff who together embark on a journey from their kingdom Arendelle. Frozen II expands the mythology behind its characters. It dives into magic, nature worship, and the betrayal of indigenous peoples by Western society. The Enchanted Forest, where a fictional indigenous community called Northuldra lives, who are modelled on the $\mathrm{Sámi}^{2}$, is where a pivotal part of the story takes place. Frozen II features religion as a founding element in the categorisation of the Northuldra people. They are characterised as a spiritual community as well as good stewards of the planet due to their understanding of the importance of the balance between the natural elements.

In the culture industries, references to indigenous religion is not a new phenomenon. For a long time, indigenous religion has been represented within experience and entertainment institutions like museums, festivals, theatres, within the film and tourism industry, as well as in the form of products of a more tangible nature like books, video games, and souvenirs (see Mathisen this issue).

1 https://www.cnbc.com/2020/01/05/frozen-2-is-now-the-highest-grossing-animated-movie-of-all-time.html (accessed on 14 May 2020).

2 The Sámi people are the indigenous people inhabiting the Arctic area of Sápmi, which encompasses parts of Sweden, Norway, Finland, and the Kola Peninsula of Russia. The Sámi are recognised under the international conventions of Indigenous people, and are the northernmost indigenous people of Europe. 
The various products are offered by professional shamans and secular agents, and by indigenous and non-indigenous alike, and they draw on trends in the spiritual milieu as well as in the experience economy. Secular and spiritual actors and institutions share an interest in landscapes of wilderness and opportunities, catering for broader audiences and for a variety of needs, including tourism, regional development, and entertainment. The phrase "arctic magic," for instance, has during the last decade been established as a common ingredient in promotional material of various sorts, with the northern Norwegian region constructed as an arctic region, situated near the borders of civilization (Bæck and Paulgaard 2012). The identification of indigenous people as a spiritual community thus seem to fit exceptionally well into contemporary structures of needs and motivations in different cultural areas beyond the religious-spiritual field. Frozen II is not the first Disney film in which indigenous religion is thematised. Films such as Pocahontas (1995), Brother Bear (2003), as well as Moana (2016) all include indigenous religious elements. In Frozen II, however, indigenous religion is the film's carrying element and the film's main character, queen Elsa, is endowed with magical powers.

The article is situated in the intersection of indigenous studies and religious studies. I explore how indigenous religion is constructed by a world leading Film Company who previously has received heavy criticism for inaccurate depictions of indigenous cultures and for exploiting indigenous cultures for profit (see for example (Norgam 2016; Yin 2014; Budd and Kirsch 2005; Edgerton and Jackson 1996). Further, I elaborate what role indigenous religion plays in the construction of Frozen II, and focus on the manner in which it is part of the commodity presented-how religion is produced, packaged, and staged. The media is an increasingly important actor in the contemporary society, and contributes to religion-making, to the flows of religion, as well as to religious change, circulation, and renewal (see Endsjø and Lied 2011; Christensen 2013; Hjarvard 2008; Partridge 2004, 2005). ${ }^{3}$ As Kraft, Tafjord, Longkumer, Alles, and Johnson argue, media and media technologies have also "contributed to the creation and maintenance of the connections, both real and imagined, that constitute emerging global indigeneities" (Kraft et al. 2020, p. 22).

Indigenous studies constitute another source of inspiration, particularly in terms of the dynamics of colonialism. In Frozen II, this theme is elaborated in terms of the Northuldra tribe and their subjection to colonial oppression and betrayal at the hands of Elsa's and Anna's grandfather, King Runeard. Like many indigenous people worldwide, the Northuldra are faced with threats to their sovereignty, their economic well-being and access to the resources on which their culture depends. As for the Sámi, whom the Northuldra people are inspired by, rough and long lasting processes of forced Christianisation and assimilation have led to loss of religion, land, languages, as well as identities.

Indigenous peoples increasingly exist in a global framework, both self-consciously drawing on globalised strategies of rights and identity, as well as being objectively situated through international legal frameworks. The Sámi have from the very beginning been engaging in indigenous people's affairs. The impact of Sámi membership in World Council of Indigenous People (WCIP) as well as their active participation in UN activities, have consequences for how Sámi issues are dealt with in regional and national contexts, as well as for the national governments' abilities to function in an international capacity (see Lehtola 2004; Minde 2003). A recent engagement is the Verdett cooperation with the Disney company where the Sámi Parliaments of Norway, Sweden, and Finland took part to ensure that the content of Frozen II is culturally sensitive and respectful of Sámi cultures.

\section{Background}

The Disney universe has appealed to audiences around the world for nearly a century. On their website, the company describes itself as one of the most prominent creators of animated children movies

3 As noted by Ingvild Sælid Gilhus and Siv Ellen Kraft Stig Hjarvard's theory of mediatisation fails to take seriously New Age forms of religion. They point out that "New Age more than "normal" institutionalized religions, are uniquely suited for late modern media-scapes, and thrive partly because of them" (Gilhus and Kraft 2017, p. 6), (see also Boutros 2011). 
and as, "a leading diversified international family entertainment and media enterprise" (Disney 2018). Frozen II is the 58th film in the series of animated Disney children classics. Chris Buck and Jennifer Lee are the film's producers and Peter Del Vecho is its director. The film is computer animated and was released in both 2D and 3D formats. Frozen II drew large crowds of audiences to the theatres, and must be considered a phenomenal box office success that earned Disney $\$ 1.45$ billion (Kandell 2020). Frozen II is the sequel to the 2013 movie Frozen, and the film's events take place three years after its predecessor. It tells a story centred on an adventure set in a time of ecological sensitivity and aims to discover the origin of Elsa's magical powers that were the primary focus in the first Frozen film. Queen Elsa keeps hearing a mysterious voice that nobody else can hear, encouraging her to start a journey into the unknown. An earthquake suddenly interferes with the idyll of Arendelle and forces everyone in the kingdom to evacuate. The Troll King, Grand Pabbie (who has the ability to heal injuries caused by magical elements, such as Elsa's power over ice and snow) and the Trolls colony arrive at Arendelle. Pabbie points out that Elsa must set things right, and re-establish harmony by discovering the truth about the kingdom's past. Remembering the voice, Elsa knows that her journey into the unknown has started and follows the voice northwards. The voice leads Elsa, Anna, Olaf, Kristoff, and Sven to the Enchanted Forest, and to the indigneous Northuldra people, who draw inspiration from the Sámi, and whose close kinship with the royal sisters, Elsa and Anna, is previously unknown (their departed mother, queen Iduna, was a member of the Northuldra tribe). Throughout the production of the film, filmmakers collaborated with Sámi experts on the depiction of the fictional Northuldra tribe. The Sámi parliaments of Norway, Sweden, and Finland, along with the transnational Sámi Council (a non-governmental organization of the Sámi people) reached out to Disney to collaborate and an advisory group, Verdett, was formed.

\section{Indigenous Religion}

In Frozen II, what is played out as religion relates to what Siv Ellen Kraft and Greg Johnson refer to as "indigenous religion" in the singular-a globalizing discourse "consisting of notions of an indigenous we and a flexible, but fairly standardized vocabulary of assumed similarities" (Johnson and Kraft 2017, p. 4). ${ }^{4}$ In the film we learn that King Runeard, Elsa's grandfather, feared the Northuldra people's magical powers and that this fear led to a betrayal of the Northuldra tribe. Like many indigenous people worldwide, Sámi people for a long time period were portrayed as skilled in magic or demonic sorcery and as heathen idol worshippers. As an example, King Christian IV in a letter dated 1609 to district Governor Claus Gagge describes the Sámi as a people who by nature were particularly apt to use magic, and he encouraged Gagge to show no mercy in cases involving Sámi sorcery (see Willumsen 2013, p. 234). During the 17th century, about 125 people were sentenced to death and to burn at the stake in the three northernmost counties of Norway. As Rune Blix Hagen argues, compared to the low population, the witch-hunts in northern Norway are some of Europe's most extensive witch processes (Hagen 2012, p. 2).

In the same way, the missionaries' accounts describe Sámi beliefs and practices as idolatry, paganism, and superstition. Nordic missionaries managed to disrupt traditional Sámi religion as a comprehensive religious system through persecution and punishment of people who used ritual drums (goavddis), through collection and destruction of ritual drums, destruction of sacred sites (sieiddit), and building of churches. One may obtain a clear sense of this destructive process from studies such as historian of religion Håkan Rydving's The End of Drum Time (Rydving 1993) that examines some aspects of the process of religious change among the Lule Sámi, when the indigenous religion was confronted with Christianity. The reformatory processes, and the missionaries' entry into local communities,

4 In comparison, indigenous religions in plural refers to distinct local traditions (Johnson and Kraft 2017, see also (Johnson and Kraft 2017). 
contributed to new religious thoughts and ideas leaving their mark on the landscape as well as the people. $^{5}$

Recently, the discussions concerning "Sámi religion" has changed. ${ }^{6}$ As a consequence of what can be called the "Indigenous turn," particularly within the arts and culture, indigenous religion is approached as a something that adds value by a range of diverse actors and for a variety of reasons. "Indigenous religion" in other words is seen as something that is worth pursuing, owning, and consuming. As Bjørn Ola Tafjord argues, in some contexts, indigenous religion has even become "a figure of power" (Tafjord 2018, p. 320; Tafjord and Alles 2018).

As stated by Kraft and Johnson, processes of indigenous revitalisation often include attempts to bring to new life ancient religious traditions that have been disrupted or erased from memory and that this appeal to religious traditions serves to open up new cultural, economic, and political horizons (Johnson and Kraft 2017). To some extent, a reversal of the primitivism of the past, the discourse on indigenous religion qualifies for Michael Shermer's notion of "the myth of the beautiful people" (Shermer 1997). Characteristics that once placed indigenous people on a lower level of the evolutionary scale today account for their position as peaceful, wise, and noble caretakers of environmental wisdom. As anthropologist Jonathan Friedman has put it:

[The] indigenous is now part of a larger inversion of Western cosmology in which the traditional other, a modern category, is no longer the starting point of a long and positive evolution of civilisation, but a voice of Wisdom, a way of life in tune with nature, a culture in harmony, a gemeinschaft, that we have all but lost. (Freidman 1999, p. 391)

Several scholars have referred to notions of a religious dimension of indigenism. According to James Clifford "Indigènitude is sustained through media-disseminated images, including a shared symbolic repertoire "the sacred," "Mother Earth," "shamanism," "sovereignty," the wisdom of "elders," stewardship over "the land" (Clifford 2013, p. 16). Popular culture, like music and film, has been important for the wider spread of such images (see Christensen 2013; Kraft 2015). The Disney Company, through the production of Frozen II, is precisely an actor who contribute to the construction and spread of religious dimensions of indigenism. The Northuldra tribe is inscribed in a romantic image and portrayed as an ecological friendly and spiritual community. They are known (and feared) for their magical skills and the name of their home, the Enchanted Forest, also gives us hints of the magical power of the people and their ancestors, as a place where the natural landscape is bonded with the spiritual world.

This type of representation of indigenous people as a community with shared religious values relating to nature, to the past, and to traditions, can be traced back to 1960s counterculture, and in particular to the interplay between the environmental movement and the New Age movement. These movements emerged within the same period, and have been exchanging ideas ever since, especially in terms of consciousness about ecology and fascination with the world's indigenous peoples.

From the late 1970 environmental concerns created a distinction in views of what could be considered sustainable forms of human development. Thomas Karl Alberts notes that, "Conservationists turned to indigenous peoples believing they could derive models from indigenous examples of sustainable use of natural resources" (Alberts 2015, p. 2). The new "ecospiritual-politics of indigenism" is also expressed in legal and political documents. For example, former UN special rapporteur José Martinez Cobo in the so-called Maritinez-Cobo report claims that there exists "a deeply spiritual relationships between indigenous peoples and their lands as basic to their existence as such and to all their beliefs, customs, traditions and culture" (Cobo 1986, p. 7). Regular references to indigenous people as children of Mother Earth are similarly common in UN-fora, along with references to a holistic worldview. As Dorothy L.

5 For more details on the Christianisation processes see Fonneland and Äikäs's introduction to this special issue.

6 "Indigenous religion" is still surrounded by negative associations and linked to primitivism and superstition in some contexts and situations, as for example within mission networks (see also Tafjord 2018). 
Hodgson notes, the UN presentations of indigenous people "draw on and reproduce familiar tropes and images of Indigenous people as colourful, spiritual 'authentic' and artistic" (Hodgson 2014, p. 62). In contrast to the "freedom of beliefs" promoted by human rights discourse, the beliefs of indigenous people tend to be explicitly connected to particular landscapes. To cite one example: ILO Convention 169, ratified by Norway in 1990, claims that governments must "respect the special importance for the cultures and spiritual values of the peoples concerning their relationship with the lands or territories" (Article 13, 1). As Thomas Karl Alberts points out,

Whereas transnational NGOs may promote essentialist representations of indigenous peoples' inherent closeness to nature, for indigenous these representations often reflect tactical choices about securing interests within structures of opportunity and constraints generated by the symbolic economy itself. (Alberts 2015, p. 132)

In other words, this new global religious-identity is partly a result of UN meetings and regulations, including laws that have helped standardise certain qualities by translating them into rights. Nevertheless, as Alberts and several researchers have pointed out, these values are also often expressed by indigenous people themselves, in their identity constructions, in the struggle for political rights and "governance value," and in cultural revitalisation processes (see Alberts 2015; Whyte 2018; Beyer 1998; Kalland 2003; Kraft 2009; Niezen 2012; Clifford 2013). Indigenous religion is thus a global discourse that attributes a particular kind of spirituality and value to indigenous peoples, while indigenous people are also able to contribute to the shaping of this discourse and to utilise it for their own more or less strategic purposes. In the following, a discussion about how indigenous religion discourses are promoted and renewed by Disney in the production of Frozen II is outlined.

\section{Reindeer, Joik, and Nature Magic as Identity Markers}

In the Enchanted Forest, Elsa discovers the origin of her magical powers and learns about the betrayal of the Northuldra tribe by her own ancestors. Due to the imbalance of the spiritual elements, the Enchanted Forest is in a state of ecological crisis, wrapped in a mist that traps the Northuldra tribe and hinders people from getting into the forest. As Elsa and her companions reach the edge of the forest, it turns out that because of Elsa's powers, the mist parts at her touch. In the forest Elsa and Anna realise that their mother, Queen Iduna, was a Northuldra who at the time of the riot saved her father, Agnarr. Elsa discovers that the voice calling to her was the memory of young Iduna's call; and that her powers were given to her by nature because of Iduna's selfless act of saving Agnarr.

In the film, the allure of the north has acquired spiritual dimensions. The Enchanted Forest, the home of the Northuldra tribe, is wrapped in a local indigenous culture situated as far north as one can go. The Northuldra people are described as a nomadic reindeer people as well as guardians of nature. They live in wooden tents that resembles the Sámi lavvo as well as in goađit (turf huts), wear clothes similar to the gákti (Sámi traditional dresses), and welcome Elsa and Anna and their companions with a joik (a traditional Sámi way of singing). The south Sámi musician and composer, Frode Fjellheim, who was invited to take part in crafting the soundscape for the first Frozen film, also composed music for the sequel, but this time the joik is performed by the Northuldra people, confirming their bond to the Sámi and to indigenous people worldwide. The joik is considered a marker of Sámi identity and was a central element in the old Sámi religion, serving in part as a tool helping the noaidi to navigate the spiritual world (see Graff 2016). In the film the joik communicates culturally specific information, and is an element that frams the Northuldra people's authenticity as well as otherness.

Reindeer herding has become a key symbol for Sámi cultures and is the most established marker of Sámi identity. The reindeer itself has gradually gained a strong symbolic power in various Sámi representations as a common denominator for Sámi cultures-and not least for indigenous status. According to folklorist Stein Mathisen, versions of Sámi reindeer-herding culture are "central symbols for a way of life that represents harmony with nature and the environment and that offers a special 
kind of indigenous, spiritual conscience" (Mathisen 2015, p. 204). In the song "Lost in the Wood," Kristoff, seeking advice from his reindeer companion Sven about how to propose to Anna, even states that "reindeer are better than people."

In Frozen II, the portrayal of the Northuldra people's interactions with their reindeer serves to demonstrate the strength of the Northuldra as a nature people. The Northuldra and their reindeer are depicted as a holistic unit and their home, the Enchanted Forest, as holding an invisible bond between people, animals, and nature. This type of portrayal that links the Northuldra community exclusively to reindeer husbandry, even though the majority of the Sámi are not part of the reindeer husbandry culture, can be said to provide a univocal understanding of Sámi identity and fails to recognize the diversity of Sámi cultures. It can be seen as a constructed "myth of origin" that both simplifies the past and excludes contradictory voices (see Mathisen 2010). In addition to a nomadic reindeer herding community, the Northuldra tribe is portrayed as a matriarchal society. The female local tribal leader is described as a wise, elder woman who is both strong and independent. She has no government or religious institutions to support her, and is a leader by virtue of her knowledge about the forces of nature. She is also the one who admonishes Elsa to trust only nature and listen when it speaks. The highlighting of female divinity is in line with the claim that media representations are gender specific, and that particular religious coverage reflects the women's emphasis on improvement (Romarheim 2011; Gresaker 2018).

In Frozen II, indigenous religion is also materialised in four natural and agentive elements in the shape of animals, nature forces, and figures of folklore. The air spirit takes the shape of a tornado, the fire spirit of an agitated salamander, the earth spirits of giants made of stone, and finally the water spirit of a nokk, a water horse who guard the sea to the glacier Atohallan ${ }^{7}$, said to contain the truth about the past. Because of King Runeard's betrayal of the Northuldra tribe, the natural elements are in imbalance and the Enchanted Forest in a state of ecological crisis. Elsa confronts and tames the tornado, the salamander and the nokk and they become her guides in search for a fifth and lost element. Anna is the one who takes care of the earth giants, not taming them, but tricking them into destroying King Runeard's dam as an act of reconciliation. The focus on nature as a door opener for establishing contact with the spiritual world and the notion that nature possesses a force that can be used for the cultivation of self and society is particularly prevalent in contemporary New Age movements. It is hard, in the landscapes explored in this case, to distinguish clearly between "New Age" and "indigenous religion", and not necessarily fruitful to do so. A close and spiritual relationship to nature is a crucial commonality, along with sacred landscapes, healing, and holism, and practices such as animism and shamanism (see Fonneland and Kraft 2013). Another denominator is the notion of self-spirituality. In Frozen II, this theme is highlighted through Elsa's travel to Atohallan in search for the fifth natural element. This is the element that she hopes will make both herself and the societies she belongs to complete, but instead of a new magical creature like the Nokk or the salamander, Elsa discovers that the fifth element is herself. In a fog of memories from her childhood, Elsa sees her mother, calling out, "you are the one you have been waiting for."

Even though Læstadianism (a Lutheran revival movement which spread among the Sámi during the late nineteenth century) gradually grew to a strong position within the Sámi community (a position it still has today), there is no mention of Læstadianism nor Christianity in the narrative that Disney elaborates. Sámi religion more than Læstadianism and Christianity reinforces the image of the Sámi culture as different from Western cultures. This also makes Sámi religion an important sign of otherness and authenticity (see also Kalvig 2020). As Kraft argues, “Due to this logic, perhaps,

7 Lauren Dundes, in the article "Elsa as Horse Whisperer in Disney's Frozen 2:Opportunity “Nokk"s to Quash Gender Stereotypes" (2020) points out that Disney fails to move past the discomfort about the confluence of women's sexuality and power. "Elsa's heroic actions fall within a category of sport in which she risks a subordinated position that does not threaten men's hegemony" (Dundes 2020, p. 3). According to Dundes, Elsa's horse-taming prowess offers the "safe" choice of pairing her with the Nokk as a surrogate human man (Dundes 2020). 
Christianity (as a "foreign" religion) has to a large extent been excluded from the Sámi national project, while pre-Christian Sámi religion has emerged as a primary source" (Kraft 2009, p. 180). The picture drawn here is of a society located in a mythical past of indigenous traditions and ceremonies that serves as a part of the "seasoning" of the Disney narrative.

The ability of popular culture to appeal to our emotions and our identification processes makes it well-suited for communicating religious ideas and ideals (Clark 2007, p. 10). The way indigenous religion is articulated in the film and linked with New Age concepts such as self-spirituality, holism, and feminism that all have secular counterparts (see Kraft 2017) inscribes Frozen II in a religious "neutral" environment, where religious symbols and values circulate almost unnoticed. This more vague form of spirituality fits perfectly to the popular media and their genres which, as Stig Hjarvard underlines, create a form of religion that appears as a part of the background owing to its implicit, "unwaved flag" qualities (Hjarvard 2011, p. 128). According to Hjarvard, because these media produced forms of religion are seldom referred to or talked about as religion and have a more implicit quality, they also spread more easily and tend to affect contemporary everyday religiosity and "become the backdrop for human knowledge about religious issues and serve to encourage "the subjectivist spiritual imagination" (Hjarvard 2011, p. 132, 2012), see also (Lied 2012). The portrayal of the Northuldra society as deeply spiritual, matriarchal, harmonious, and ecologically sensitive and Elsa's self-development and her strive for the balancing of the elements, in other words contributes to a cultural repertoire that serves to promote indigenous religion as a Sámi identity marker (see also Christensen 2013; Christensen and Kraft 2011).

\section{The Bridge Conflict}

In Frozen II, local stories and materialities are connected to a global network and global categories. One such example is the story that is the basis of the plot itself and that reveals the betrayal of the Northuldra people. King Agnarr of Arendelle tells a story to his young children, Elsa and Anna, about how their grandfather, King Runeard, established a treaty with the neighbouring tribe of Northuldra by building a dam in the Enchanted Forest. However, the treaty failed and a fight occurred in which king Runeard was killed and the elemental spirits of Earth, Fire, Water, and Air of the forest were enraged. Entering the Enchanted Forest and confronting the past Elsa learns "the real story," namely that her grandfather wanted to build the dam as a ruse to reduce the Northuldra's resources and that he intended to incorporate the region into his kingdom. She also learns that he was the one who initiated the conflict by killing the unarmed leader of the Northuldra tribe.

The bridge conflict in Frozen II shines a light on a Sámi indigenous issue from the real world, namely the construction of a hydroelectric plant in the Alta-Kautokeino River (1979-1981) in a substantial reindeer herding area where the dam would disrupt reindeer migration and traditional salmon fishing and also flood and displace the Sámi village Máze. ${ }^{8}$ Still, the Alta affair represented something more than concerns for the reindeer and the environment. The demonstrations, roadblocks, and hunger strikes that took placed in connection with the "Alta affair" sparked a Sámi ethnic revival, and are generally regarded as the beginning of the Sámi cultural revival movement (Hætta 2002). They also served as premises for what the founding father of shamanism in Norway, Ailo Gaup has referred to as the 78 generation-the Sámi version of the 1968-generation (see Fonneland 2017), The Sámi 1978 generation consisted of young people as well as scholars, musicians, and artists who had more or less been cut off from the Sámi culture and language and who wanted to improve the political situation of the Sámi people. This was a generation whose parents, due to strong assimilation processes, had shielded their children from a cultural baggage they considered shameful, in order to secure them a better life and more positive prospects (see Fonneland and Kraft 2013, p. 133). After a prolonged period of acts of civil disobedience, hunger strikes, and an occupation of the Prime minister's office 
(see Alver 2015), the decision was effectuated in January 1981, against massive protests. Despite the building of the plant, the Sámi won a victory in achieving a positive outlook for Sámi autonomy. Thanks to the Alta conflict the Sámi achieved a great deal both when it comes to publicity, an extended focus on Sámi rights, and it also put the question of Sámi indigenous status on the national political agenda" (see Thuen 1995, p. 13). In 1989, The Sámediggi (Sámi Parliament) was established and the Indigenous and Tribal Peoples Convention 1989 No 169 (ILO 169) was ratified by Norway the following year.

What the producers of Frozen II has added that differs from the real story, in addition to destroying the dam, is the staging of indigenous religion as a key element in the bridge affair. As Siv Ellen Kraft has pointed out, the Alta-conflict was stripped of religious symbols and references. Only more revitalized secular symbols like the gákti, the lavvo, as well as other examples of duodji (traditional Sámi handcraft) were displayed (Kraft 2020). In Frozen II, the Northuldra tribe is recognised as an indigenous community precisely due to the display of indigenous religious references. Religion in Frozen II is no longer absent, but a core of the bridge conflict. In the film, the highlighting of religion as a key feature of the conflict is a tool that marks the Northuldra as a distinct people, rooted in a magical landscape and living in harmony with their natural surroundings. This cultural marker is defined as a binary to Western society, religions, and worldviews, in this case, the people of Arendelle who are portrayed as more modern and disconnected from Mother Earth, and the Northuldra tribe as her protectors.

\section{An American Story}

Frozen II mediatizes Sámi indigenous religion in a globalised form. In this global religion, all local elements that do not travel well in the Disney universe are wiped out and those that do are remodelled and assimilated to wider global idioms and interests. The film's producer, Peter Del Vecho, visited the Sámi parliament in Kárášjohka in October 2018 and in an interview with the national broadcasting company NRK Sápmi, he precisely states that: "The Sámi culture has a unique history. We are very interested in different angles, so we can try to make films that appeal universally. That is why we are here." ${ }^{9}$ Frozen II in other words is an American story, where the local materialities, knowledge, and traditions are moved to and shaped by a global setting to appeal to a global audience.

Contemporary old Sámi religious symbols are no longer as stigmatised, but revitalised (see Joy this volume) and embedded in new contexts, practices, and meanings (see Äikäs and Spangen this volume, and Kraft this volume). Despite the reversal of status and these symbols' present-day position as Sámi cultural heritage, no specific religious symbols or characters are staged in Frozen II. The film is stripped of the goavvdis (Sámi ritual drums), the sieiditt (Sámi sacrificial stones), as well as the noaidi (Sámi religious specialist), which are the most well-known markers of the ethnic religion of the Sámi indigenous population.

This way of adapting local markers to a global market can be seen as an example of what Siv Ellen Kraft and Greg Johnson refer to as, "scalar translations," namely "ways in which locally specific objects and actions gain relevance outside of their site-specific locations and contexts, as belonging to the broader indigenous we and our" (Johnson and Kraft 2017, pp. 6-7) ${ }^{10}$. In Frozen II, this process of scalar translations have blurred the more locally specific elements and brought a focus on more indefinite characteristics of indigenous religion. The directors describe the Northuldra religion as

9 https://www.nrk.no/sapmi/oscar-vinner-og-frost-2-produsent_-_den-samiske-kulturen-har-en-unik-historie-1.14230144 (accessed on 21 May 2020), translation by author (Den samiske kulturen har en unik historie. Vi er svært interesserte i forskjellige innfallsvinkler, så vi kan prøve å lage filmer som appellerer universelt. Derfor er vi her).

10 There is also a wise versa to the "Scalar translations"story, namely, "how globalizing idioms are anchored in the local we" (Johnson and Kraft 2017, pp. 6-7). In terms of Frozen II, it remains to be seen how its religion-making will be stated in terms of new images, figures, or realities. The tourism operator Visit Norway together with the Disney Company have already arranged a press tour for international journalists throughout Sápmi to discuss how Frozen II can serve as a means for increasing tourism to the region (https://www.nrk.no/sapmi/haper-pa-turistboom-etter-_frost-2_-1.14782432 (accessed on 2 May 2020)). 
an indistinct form of spirituality; a spirituality embedded in indigenous ways of life and thinking, and with a focus on concepts such as holism, environmental protection, feminism, ancestral anchorage, and nature worship.

As Janet Wasko (2001) argues, the Disney Company has form the very start "Disneyfied" fairy tales and folktales by adapting them as a source material for their classic children animations to make them appealing for Western audiences. The Disneyfication process in other words comprises an adaption, simplification, Americanisation, or westernisation of the original source material (see Wasko 2001; Zipes 1999; Giroux and Pollock 2010; Griffin et al. 2017). In Frozen II, the source material that Disney builds on is not a not a fairy tale or folktale, but Sámi cultures and religion are here framed to fit with the Disney fairy tale standard. ${ }^{11}$ As the film's director Peter Del Vecho announced to NRK Sápmi, Disney's goal is precisely to transform Sámi cultures and religion to make the source material "universal" and attractive to theatregoers globally.

The Sámi religious symbols in Frozen II are part of a global arrangement, and it is within these frameworks that patterns of knowledge and practice transmitted from the local community become alive in the Disney universe. Considering the indigenous religion staged in Frozen II, it is impossible to draw a line between the global and the local. Although the symbols chosen have their roots in a local context, their performance takes into account global flows. These circulations of religious thematics and symbols through scalar translations call our attention to religious change, and the flexibility and capacity of religion in processes of mediation.

When a company such as Disney chooses to use indigenous religion as a main source material, it is important to highlight the power dynamics involved. Despite the huge success of Disney's fairy tale films, many critics object to the way the fairy tales have been adapted. As Jack Zipes argues, the Disney corporation is attempting to impose American value systems upon the rest of the world in a deliberately political, colonizing, or imperialist way (Zipes 1999). Rather than viewing staging of indigenous religions in Frozen II as a discourse that is exclusively imposed from outside, an equally important approach is to discuss how indigenous people are also able to contribute to the shaping of this discourse and to utilise it for their own more or less strategic purposes (see also Christensen 2013).

\section{Framing Otherness through Collaboration-Conclusions}

Several of Disney's film productions have been heavily criticized for cultural appropriation and inaccurate depictions of indigenous cultures (see for example Norgam 2016; Yin 2014; Budd and Kirsch 2005; Edgerton and Jackson 1996). Pocahontas (1995) is one of the Disney animations that has drawn heavy criticism from indigenous communities for whitewashing and erasing a genocidal history (see Ristola 2020). Cultural appropriation refers to processes of asymmetrical cultural exchanges in which one part exploits elements from the culture of a part whose position is significantly weaker (see Clifford 1983; Comaroff and Comaroff 2009). Accusation of appropriation was also the case for the first Frozen film, launched in 2013. The film opened with a song inspired by traditional Indigenous joik and Kristoff wore clothes that resembled the Sámi gákti, but there was no mention of the origin of the song nor clothes and no permission was sought from the Sámi people. After the debates about cultural appropriation that surrounded Frozen, Disney decided to lay the ground for a more sustainable indigenous cultural policy in the sequel. That the criticism connected to the first Frozen film generated changes in terms of the production of Frozen II, marks a transition in the balance of power and representation. As Michelle Anya Anjirbag points out,

It is also arguable that in the past two decades, the shift from sending a production team on a research trip and engaging consultants as needed, to deliberately involving people who are of and invested in a particular culture to be part of the adaptation and storytelling

11 The first Frozen film is said to build loosely on The Snow Queen by Hans Christian Andersen, while Frozen II has no source material that is related to a particular folktale or fairytale. 
process, marks a significant change in how Disney has approached telling stories from other cultures. This latter move is, at face value, a positive step, as the studio begins a necessary process of potentially moving away from appropriating and transforming cultural property in decontextualized ways and perpetuating harmful, often colonializing, stereotypes. (Anjirbag 2018, p. 13)

A collaboration between the Walt Disney Company, the transnational Sámi Council, and Sámi parliaments of Norway, Sweden, and Finland was established and a so called Verdett-advisory group ${ }^{12}$ of Sámi artists, authors, scholars, and political leaders was formed. All parts also signed a contract that outlines Disney's desire to "collaborate with the Sámi in an effort to ensure that the content of Frozen II is culturally sensitive, appropriate and respectful of the Sámi and their culture."13 Disney agreed to produce a dubbed version of the movie in the North Sámi language titled Jiknon that was released 25 December 2019 at the same time as the Norwegian, Frost $2 .{ }^{14}$ Cross-learning initiatives where Sámi filmmakers and animators will have the chance to head to California for internships with Disney were also initiated. In several media coverings, the members of the Verdett-group praise the cooperation with the Disney Company. Ánne Lajla Utsi, director of Internášunála Sámi Filbmainstituhtta (The International Sámi Film Institute) underlines that: "It has been a very, very good collaboration, I must say. We are really proud of that, and happy about the film, as it is now."15

Frozen II in other words can be seen as Disney's redevelopment project encouraged by what Ronald Niezen has termed "the politics of shame" - "the effort to influence a decision or policy through dissemination of information to an audience that is a source of political power, information that exposes the inappropriateness, harm, or illegality of a course of action" (Niezen 2003, p. 179). The politics of shame is thus nourished by a general understanding of the colonialization process as a blemish history of the West, and of indigenous people's right to speak back (Niezen 2003). In the case of Frozen II, these politics generated new cultural policies and practices which sought to establish positive alternatives to appropriation, and the collaboration with the Verdett group has obviously been important for the film's legitimacy, as well as for its role as a contributor to Sámi indigenous religion.

In a research context, there has been a tendency to describe romantic indigenous images as an expression of destructive exotification, largely under the auspices of New Agers, and when religious symbols are branded and packaged through media or in tourism settings, issues of commodification, religious authenticity, as well as dilution of spiritual value are often raised (Vukonic 2002; Zaidman 2003). The processes involved in the production of Frozen II and the portrayal of the Northuldra tribe as an indigenous spiritual community, are still more complex than a construction of a romanticised other. Through a close cooperation with the Disney Company, indigenous people were able to contribute to the shaping of the indigenous religion discourse and in this process indigenous religion also becomes part of broader functional apparatuses linked to contemporary politics, economy, and to what James Clifford describes as ongoing processes of "becoming indigenous" (Clifford 2013).

Limited scholarly attention has been directed to cases "in which marginalised sociocultural communities have adopted the language of religion as a means of empowerment vis-à-vis assimilationist politics directed against them" (Dressler and Mandair 2011, p. 22). The production of Sámi indigenous religion in Frozen II can be described as processes of religion-making. Religion-making, according to a model developed by Markus Dressler and Arvind Mandair, is expressed on diverse arenas and is a process that emerges from various positions of power and that also comprise secular institutions

12 The north Sámi word verdett refers to the word friends or more precisely "guest friends." The Sámi Verde-system is an informal arrangement that lasts over time where two or more people/families exchange services.

13 https://nowtoronto.com/movies/news-features/disney-frozen-2-indigenous-culture-sami (accessed on 31 May 2020).

14 The Internášunála Sámi Filbmainstituhtta (The International Sámi Film Institute), which took over the production of the Sámi dubbing, had previously asked, back in 2013, to dub Frozen, but Disney declined their request. Frozen II is the third film to receive a special dubbing.

15 https://www.sofn.com/blog/sami-culture-represented-in-frozen-2/ (accessed on 5 May 2020). 
(Dressler and Mandair 2011; Dressler 2019). They point out that that religion-making from below forms a dialectical relationship with religion-making from above, and that attention needs to be given to the "more complex dynamics of agency in the adaptation of these discourses in non-Western vernacular languages" (Dressler and Mandair 2011, p. 22) With reference to Charles Halisey's concept of intercultural mimesis ${ }^{16}$, they argue that,

We need to think the appropriation of the Western discourses of religion and the secular in a manner that does not reduce local actors to the role of passive objects but instead focuses on "local productions of meaning," that is, the agency of locals in the encounter with Orientalist knowledge. (Dressler and Mandair 2011, p. 22)

In Frozen II, a narrative about the Northuldra community and its members takes shape through the selection and interpretations of the "local" and "traditional," and through the activation of different symbols and events that are highlighted as particularly meaningful for the Sámi community. This narrative underpins and develops discourse about indigenous religion by presenting the Enchanted Forest and the Northuldra culture as spiritual, close to nature, in balance with the natural elements, and associated with ancient traditions. In Frozen II, Sámi religion is portrayed as a living and valuable symbol. Here, Sámi religion is no longer a cultural stigma and a reminder of a pagan past, but a powerful, authentic, and magical symbol for a living Sámi culture.

Cultural forms will always be shaped and reshaped. Tradition is not an objective capacity with roots in the past, but rather something dynamic and shifting-a contemporary man-made process that facilitates a symbolic construction of relationships between past and present (see Handler and Linnikin 1984). The signposting of indigenous religion in Frozen II is a result of complex, innovative processes where cultural elements from the past are reframed, transformed, retrieved, and added new and positive value in order to create awareness about Sámi identity, culture, and politics. The religious images emerge not from ethnographic documentation but from an imaginative construction stimulated by contemporary encounters.

Funding: The publication charges for this article have been funded by a grant from the publication fund of UiT The Arctic University of Norway.

Conflicts of Interest: The author declares no conflict of interest.

\section{References}

Alberts, Thomas Karl. 2015. Shamanism, Discourse, Modernity. Ashgate: Surrey and Burlington.

Alver, Bente G. 2015. More or Less Genuine Shamans!: The Believer in an Exchange between Antiquity and Modernity, between the Local and the Global. In Nordic NeoShamanisms. Edited by Trude Fonneland, Siv Ellen Kraft and James Lewis. London: Palgrave MacMillan, pp. 141-74.

Anjirbag, Michelle Anya. 2018. Mulan and Moana: Embedded Coloniality and the Search for Authenticity in Disney Animated Film. Social Sciences 7: 230. [CrossRef]

Bæck, Unn D., and Gry Paulgaard. 2012. Introduction: Choices, Opportunities and Coping in the Face of Unemployment. In Rural Futures? Finding One's Place within Changing Labour Markets. Edited by Unn-Doris Bæck and Gry Paulgaard. Stamsund and Oslo: Orkana Akademisk Forlag.

Beyer, Peter. 1998. Globalisation and the Religion of Nature. In Nature Religion Today. Paganism in the Modern World. Edited by Pearson Joanne, Geoffrey Samuel and Richard H. Robers. Edinburgh: Edinburgh University Press, pp. 11-21.

Boutros, Alexandra. 2011. Gods on the Move: The Mediatisation of Vodou. Culture and Religion 12: 185-201. [CrossRef]

Budd, Mike, and Max Kirsch. 2005. Rethinking Disney: Private Control, Public Dimensions. Middletown: Wesleyan University Press.

16 Halisey is in this chapter paraphrased in Richard King's Orientalism and Religion (King 1999, p. 148). 
Christensen, Cato, and Siv Ellen Kraft. 2011. Religion i Kautokeino-opprøret. En analyse av samisk urfolksspiritualitet. Nytt Norsk Tidsskrift 2011: 18-26.

Christensen, Cato. 2013. Religion Som Samisk Identitetsmarkør: Fire Studier av Film. Ph.D. Dissertation, Department of History and Religious Studies, University of Troms $\varnothing$, Tromsø, Norway.

Clark, Lynn Schofield. 2007. Why Study Popular Culture? Or, How to Build a Case for your Thesis in a Religious Studies or Theology Department. In Between Sacred and Profane: Researching Religion and Popular Culture. Edited by Gordon Lynch. London: I.B. Tauris, pp. 5-20.

Clifford, James. 1983. On Collecting Art and Culture. In The Predicament of Culture: Twentieth-Century Ethnography, Literature, and Art. Cambridge, Massachusetts: Harvard University Press.

Clifford, James. 2013. Returns. Becoming Indigenous in the Twenty-First Century. London: Harvard University Press.

Cobo, José R. Martinez. 1986. Study of the Problem of Discrimination against Indigenous Populations. Vol V, Conclusions, Proposals and Recommendations UN Doc E/CN.4/Sub. 2. New York: UN.

Comaroff, John L., and Jean Comaroff. 2009. Ethnicity, Inc. Chicago and London: Chicago University Press.

Disney. 2018. "About the Walt Disney Company". The Walt Disney Company Website. Available online: https://www.thewaltdisneycompany.com/about/ (accessed on 1 June 2020).

Dressler, Markus, and Arvind-Pal S. Mandair. 2011. Secularism and Religion-Making. New York: Oxford University Press.

Dressler, Markus. 2019. Modes of Religionization: A Constructivist Approach to Secularity. Working Paper Series of the HCAS Multiple Secularities—Beyond the West, Beyond Modernities 7. Leipzig: Leipzig University.

Dundes, Laura. 2020. Elsa as Horse Whisperer in Disney's Frozen 2: Opportunity "Nokk"s to Quash Gender Stereotypes. Social Sciences 9: 86. [CrossRef]

Edgerton, Gary, and Kathy Merlock Jackson. 1996. Redesigning Pocahontas: Disney, The “White Man's Indian” and the Marketing of Dreams. Journal of Popular Film and Television 24: 90-99. [CrossRef]

Endsjø, Dag Ø., and Liv I. Lied. 2011. Det Folk Vil Ha: Religion og Populærkultur. Oslo: Universitetsforlaget.

Fonneland, Trude, and Siv E. Kraft. 2013. Sami Shamanism and Indigenous Spirituality. In New Age Spirituality: Rethinking Religion. Edited by Ingvild Gilhus and Steven Sutcliffe. London: Equinox Publishers, pp. 132-45.

Fonneland, Trude. 2017. Contemporary Shamanisms in Norway. Religion, Entrepreneurships and Politics. Oxford: Oxford University Press.

Freidman, James. 1999. Indigenous struggle and the discreet charm of the bourgeoisie. Journal of World-Systems Research 2: 391-411.

Gilhus, Ingvild Sælid, and Siv E. Kraft. 2017. Introduction: New Age in Norway. In New Age in Norway. Edited by Ingvild Sælid Gilhus, Siv E. Kraft and James Lewis. London: Equinox Publishers, pp. 1-18.

Giroux, Henry A., and Grace Pollock. 2010. The Mouse That Roared: Disney and the End of Innocence. Lanham: Rowman and Littlefield.

Graff, Ola. 2016. Joikeforbudet i Kautokeino. Musikketnologisk, Historisk Analyse av Kulturutvikling i etterkrigstida $i$ Kautokeino. Karasjok: Davvi Girji.

Gresaker, Ann K. 2018. Relevant Religion. Nordiske Livsstilbladers Fremstillinger av Religion 1988-2008. Doctoral thesis, The University of Oslo, Oslo, Norway.

Griffin, Martyn, Nancy Harding, and Mark Learmonth. 2017. Whistle While You Work? Disney Animation, Organizational Readiness and Gendered Subjugation. Organization Studies 38: 869-94. [CrossRef]

Hætta, Odd M. 2002. Samene: Nordkalottens Urfolk. Oslo: Cappelen Damm.

Hagen, Rune. 2012. Innledning. In Ottar: Om Heksebrenning i Nord. Ottar, populærvitenskapelig tidsskrift fra Tromsø Museum. No 293 (5). Tromsø: Lundblad Grafisk, p. 2.

Handler, Richard, and Jocelyn Linnikin. 1984. Tradition, Genuine or Spurious. Journal of American Folklore 97: 273-390. [CrossRef]

Hjarvard, Stig. 2008. The mediatization of religion. A theory of the media as agents of religious change. Nordicom Review 29: 105-34. [CrossRef]

Hjarvard, Stig. 2011. The Mediatisation of Religion: Theorising Religion, Media and Social Change. Culture and Religion 12: 119-35. [CrossRef]

Hjarvard, Stig. 2012. Three Forms of Mediatized Religion. In Mediatization and Religion: Nordic Perspectives. Edited by Stig Hjarvard and Mia Lövheim. Gøteborg: Nordicom, pp. 21-44.

Hodgson, Dorothy L. 2014. Culture Claims: Being Maasai at the United Nations. In Performing Indigeneity: Global Histories and Contemporary Experiences. Edited by Graham Laura R. and H. Glenn Penny. Lincoln and London: University of Nebraska Press, pp. 55-82. 
Johnson, Greg, and Siv E. Kraft. 2017. Introduction. In The Brill Handbook of Indigenous Religion(s): Pathways—Being, Becoming, Back. Edited by Greg Johnson and Siv E. Kraft. Leiden and Boston: Brill, pp. 1-24.

Kalland, Arne. 2003. Environmentalism and Images of the Other. In Nature across Cultures. Views of Nature and the Environment in Non-Western Culture. Edited by Helaine Selin. Amsterdam: Kluwer Academic Publishers, pp. 1-17.

Kalvig, Anne. 2020. Available online: https://klassekampen.no/utgave/2020--01-09/vinden-gjev-svar (accessed on 28 May 2020).

Kandell, Zachary. 2020. Why Frozen 2 Was A Disappointment. ScreenRant.com, March 16. Available online: https://screenrant.com/frozen-2-movie-disney-sequel-disappointing-bad-reason/ (accessed on 28 May 2020).

King, Richard. 1999. Orientalism and Religion. London and New York: Routledge.

Kraft, Siv E., Bjørn Ola Tafjord, Arkotong Longkumer, Gregory D. Alles, and Greg Johnson. 2020. Introduction. In Indigenous Religion(s): Local Grounds, Global Networks. Edited by Arkotong Longkumer, Siv Ellen Kraft, Bjørn Ola Tafjord, Gregory D. Alles and Greg Johnson. London and New York: Routledge, pp. 1-20.

Kraft, Siv E. 2009. Sámi Indigenous Spirituality. Religion and Nation Building in Norwegian Sápmi. Temenos. Nordic Journal of Comparative Religion 45: 179-206. [CrossRef]

Kraft, Siv E. 2015. Shamanism and Indigenous Soundscapes: The Case of Mari Boine. In Nordic NeoShamanisms. Edited by Trude Fonneland, Siv E. Kraft and James Lewis. London: Palgrave MacMillan, pp. 235-62.

Kraft, Siv E. 2017. Bad, Banal and Basic: New Age in the Norwegian News Press and Entertainment Media. In New Age in Norway. Edited by Ingvild Sælid Gilhus, Siv E. Kraft and James Lewis. London: Equinox Publishers, pp. 65-78.

Kraft, Siv E. 2020. Indigenous Religion(s) - In the Making and on the Move: Sámi Activism from Alta to Standing Rock. In Indigenous Religion(s): Local Grounds, Global Networks. Edited by Arkotong Longkumer, Siv Ellen Kraft, Bjørn Ola Tafjord, Gregory D. Alles and Greg Johnson. London and New York: Routledge, pp. 59-88.

Lehtola, Veli P. 2004. The Sámi People. Traditions in Transition. Inari: Kustannus Puntsi Publisher.

Lied, Liv I. 2012. Religious Change and Popular Culture with a Nod to the Mediatization of Religion Debate. In Mediatization and Religion: Nordic Perspectives. Edited by Stig Hjarvard and Mia Lövheim. Gøteborg: Nordicom, pp. 183-201.

Mathisen, Stein R. 2015. Contextualizing exhibited versions of Sami Noaidevuohta. In Nordic Neoshamanisms. Edited by Trude Fonneland, Siv E. Kraft and James Lewis. New York: Palgrave Macmillan, pp. 191-213.

Mathisen, Stein R. 2010. Indigenous spirituality in the touristic borderzone. Temenos, Nordic Journal of Comparative Religion 46: 53-72. [CrossRef]

Minde, Henry. 2003. The challenge of indigenism: the struggle for Sami land rights and self-government in Norway 1960-1990. In Indigenous Peoples: Resource Management and Global Rights. Edited by Svein Jentoft, Henry Minde and Ragnar Nilsen. Delft: Eburon Academic Publishers, pp. 75-106.

Niezen, Ronald. 2003. The Origins of Indigenism: Human Rights and the Politics of Identity. Berkeley: University of California Press.

Niezen, Ronald. 2012. Indigenous Religion and Human Rights. In Religion and Human Rights. An Introduction. Edited by John Witte and M. Christian Green. Oxford: Oxford University Press, pp. 119-34.

Norgam, Piia. 2016. «Kaikkien omaisuutta?». Available online: https://hairikot.voima.fi/artikkeli/kaikkienomaisuutta (accessed on 28 May 2020).

Partridge, Cristopher. 2004. The Re-Enchantment of the West. London: TandT Clark, vol. 1.

Partridge, Christopher. 2005. The Re-Enchantment of the West. London: TandT Clark, vol. 2.

Ristola, Jaqueline. 2020. Available online: https://blog.animationstudies.org/?p=3431 (accessed on 7 July 2020).

Romarheim, Arild. 2011. Nyåndelig folkereligiøsitet. In Nye Guder for Hvermann? Femti år Med Alternative Spiritualitet. Edited by Tormod Engelsviken, Og Olsen, Rolv og Thelle and Notto R. Trondheim: Tapir forlag, pp. 41-60.

Rydving, Håkan. 1993. The End of Drum-Time. Religious Change among the Lule Saami, 1670s-1740s. Historia Religionum 12. Uppsala: Acta Universitatis Upsaliensis.

Shermer, Michael. 1997. The Myth of the Beautiful People. Why the Grass is Always Greener in the Other Century. Skeptic Magazine 5: 72-9.

Tafjord, Bjørn Ola, and Gregory D. Alles. 2018. Introduction: Performances and mediations of indigenous religion(s). Numen 65: 457-66. [CrossRef] 
Tafjord, Bjørn Ola. 2018. Modes of Indigenizing: Remarks on Indigenous Religion as a Method. International Journal for the Study of New Religions 9: 303-27. [CrossRef]

Thuen, Trond. 1995. Quest for Equity: Norway and the Saami Challenge. St. John's Newfoundland: Institute of Social and Economic Research.

Vukonic, Boris. 2002. Religion, tourism and economics: a convenient symbiosis. Tourism, Recreation Research 27: 59-64. [CrossRef]

Wasko, Janet. 2001. Understanding Disney: The Manufacture of Fantasy. Cambridge: Polity; Malden: Blackwell.

Whyte, Kyle. 2018. What do indigenous knowledges do for indigenous peoples? In Traditional Ecological Knowledge: Learning from Indigenous Practices for Environmental Sustainability. Edited by Melissa K. Nelson and Dan Shilling. Cambridge: Cambridge University Press, pp. 57-82.

Willumsen, Helene. 2013. Witches of the North: Scotland and Finnmark Studies in Medieval and Reformation Traditions v.170. Leiden and Boston: Brill.

Yin, Jing. 2014. Popular Culture and Public Imaginary: Disney vs. Chinese Stories of Mulan. In The Global Intercultural Communication Reader. Edited by Molefi Kete Asante, Yoshitaka Miike and Jing Yin. Oxon: Routledge, pp. 285-30.

Zaidman, Nurit. 2003. Commercialization of religious objects: a comparison between traditional and New Age religions. Social Compass 50: 345-60. [CrossRef]

Zipes, Jack. 1999. Breaking the Disney Spell. In The Classic Fairy Tales. Edited by Maria Tatar. New York: W.W. Norton and Company, pp. 332-52.

(C) 2020 by the author. Licensee MDPI, Basel, Switzerland. This article is an open access article distributed under the terms and conditions of the Creative Commons Attribution (CC BY) license (http://creativecommons.org/licenses/by/4.0/). 